\title{
Phosphorus Fluxes at the Sediment-Water Interface in a Temperate Region Agricultural Catchment
}

\author{
Jingjun Su • Eric van Bochove • Jean-Christian Auclair • \\ Georges Thériault • Chengxiao $\mathrm{Hu} \cdot$ Xuyong $\mathrm{Li}$
}

Received: 25 September 2012 / Accepted: 30 August 2013 /Published online: 13 December 2013

(C) Springer Science+Business Media Dordrecht 2013

\begin{abstract}
Phosphorus (P) release and flux at sedimentwater interface was hypothesized to vary with studied catchment branches due to differences in water chemistry of recharging groundwater. Stream water, seepage water, groundwater, and resurgence groundwater were collected, and their dissolved reactive P (DRP) concentrations and related water chemistry variables $(\mathrm{pH}$, dissolved oxygen, cations, and anions) were measured to identify $\mathrm{P}$ sources in seepage water and resurgence groundwater and to look into their impacts on stream water DRP. Results showed that the groundwatercarried $\mathrm{P}$ concentrations were negligible, and, thus, not a direct source of DRP to stream water. However, the
\end{abstract}

J. Su $\cdot$ X. Li

State Key Laboratory of Urban and Regional Ecology,

Research Center for Eco-Environmental Sciences,

Chinese Academy of Sciences,

\#18 Shuangqing RoadHaidian District,

Beijing 100085, China

J. Su

e-mail: jjsu@rcees.ac.cn

X. Li

e-mail: xyli@rcees.ac.cn

E. van Bochove $(\bowtie)$

Office of Knowledge and Technology Transfer, Science and

Technology Branch, AAFC,

2828, boulevard Laurier, Quebec G1V 0B9, Canada

e-mail: eric.vanbochove@agr.gc.ca

J.-C. Auclair

Institut national de la recherche scientifique-Eau,

Terre et Environnement,

490 de la Couronne, Quebec G1K 9A9, Canada

e-mail: jean-christian.auclair@ete.inrs.ca upwelling groundwater could contribute to stream water DRP by dissolving calcite-bound $\mathrm{P}$ in top sediments of branch 15 . The seepage experiment indicated that in branch14, sediment release of reducible $\mathrm{P}$ was minimal. Furthermore, the presence of impermeable clay layer over the streambed of branch 14 prevented the transport of water and nutrients from beneath sediments to stream water, further reducing the $\mathrm{P}$ flux across the sedimentwater interface. This study revealed that in branch 14 , the recharge of anoxic groundwater did not significantly influence stream water $\mathrm{P}$, due directly to its low $\mathrm{P}$ concentration, or indirectly to the lack of reducible $\mathrm{P}$ and the poor hydrological connectivity in bottom

\section{G. Thériault}

Soils and Crops Research and Development Center, Agriculture and Agri-Food Canada, 2560 Hochelaga Boulevard, Quebec G1V2J3, Canada e-mail: Georges.Theriault@agr.gc.ca 
sediments. These results showed that differences between $\mathrm{P}$ soluble concentrations in small catchment streams can be explained by physicochemical processes at the sediment-water interface. More investigation is needed to assess whole catchment $\mathrm{P}$ dynamics.

Keywords Phosphorus · Source · Groundwater .

Sediment-water interface

$\begin{array}{ll}\text { Abbreviations } \\ \text { Br14 } & \text { Branch 14 } \\ \text { Br15 } & \text { Branch 15 } \\ \text { DO } & \text { Dissolved oxygen } \\ \text { DRP } & \text { Dissolved reactive phosphorus } \\ \text { HDPE } & \text { High-density polyethylene } \\ \text { ICP-OES } & \text { Inductively coupled plasma-optical } \\ & \text { emission spectrometry } \\ \text { K-W } & \text { Kruskal-Wallis } \\ \text { LOI } & \text { Loss on ignition } \\ \text { P } & \text { Phosphorus }\end{array}$

\section{Introduction}

Phosphorus (P) is widely regarded as a limiting nutrient for primary production in the aquatic system, and excessive $\mathrm{P}$ concentrations were mainly responsible for eutrophication in shallow lakes (Conley et al. 2009). The important role of the sediment-water interface in regulating the $\mathrm{P}$ cycle in freshwater has been well established (Eckert et al. 1997). On one hand, sediments could act as the sink of $\mathrm{P}$ by forming mineral-P complexes; and on the other hand, sediments could release $\mathrm{P}$ back to water column and become a major source of internal P loading. Under certain conditions, $P$ flux from sediments can be sufficient to enhance the eutrophication process (Moore et al. 1998).

Studies of P flux from sediments to overlying water have usually shown that redox conditions, $\mathrm{pH}$, temperature, microbial activity, and pore water dissolved reactive phosphorus (DRP) concentrations strongly influence P release (Moore et al. 1998; Wang et al. 2012). High $\mathrm{pH}$ values result in a competitive exchange of phosphate anions with $\mathrm{OH}^{-}$, increasing the potential to release P (Christophoridis and Fytianos 2006), while low $\mathrm{pH}$ could cause hydroxyapatite dissolution (Lindsay et al. 1989). Microbial activity could play a vital role in degradation of organic matter, liberating soluble P from sediments and dead plants (Pagès et al. 2011; Qian et al. 2011). Elevated temperature could enhance the processes governing P release and transfer such as organic mineralization, microbial metabolic processes, and solute chemical diffusion (Wang et al. 2012).

Redox conditions at the sediment-water interface are the classical explanation of sediment-water interactions (Søndergaard et al. 2003). In oxidized conditions, P is sorbed to iron (III) compounds, while in anoxia, iron (III) is reduced to iron (II) and subsequently both iron and sorbed phosphate returned into solution (Einsele 1936; Mortimer 1941). Moore et al. (1998) found that anaerobic conditions promoted large P fluxes in the top few centimeters of the sediments in Lake Okeechobee, Florida. Grunth et al. (2008) observed a decreased thickness of the oxidized surface sediment layer accompanied by the $\mathrm{P}$ release due to the depletion of dissolved oxygen in overlying water. Some studies further pointed out that $\mathrm{P}$ bound to amorphous and poorly crystalline forms of $\mathrm{Fe}$ and $\mathrm{Mn}$ (bicarbonate-dithionite-P) explained $53 \%$ of the variance in hypolimnetic TP, while only $8 \%$ was explained by the proportion of sediment organic matter (Pant and Reddy 2001; Petticrew and Arocena 2001). While several workers have evaluated $P$ exchange across the sediment-water interface of lakes, reservoirs, and wetlands (Moore et al. 1998; Wang et al. 2012; Gunnars and Blomqvist 1997; Haggard et al. 2005; Lavoie and Auclair 2012; Redshaw et al. 1990), we know of very little research that has studied these processes in flowing rivers or streams.

Our study was undertaken in two major branches (Br14 and Br15) located within an intensive livestock catchment in Quebec, Canada. The two branches were fed by a mix of groundwater with contrasting chemistry due to in situ heterogeneous hydrogeologic conditions (Corriveau et al. 2010a). Br14 was mainly supplied by the regional aquifer where anoxic conditions prevail, while $\mathrm{Br} 15$ was mainly connected to the surficial aquifer which was characterized by high dissolved oxygen concentrations (Corriveau et al. 2010a). This contrast in redox status of aquifer systems had partly explained the significant differences of $\mathrm{NO}_{2}^{-}$concentration in the seepage water collected in the two branches. We hypothesized that this contrast in aquifer redox status may also produce contrast in redox-gradient from the lower sediment layer to overlying water column in the two branches as groundwater moved upward. Therefore, the objective of this study was to understand if the upwelling groundwater recharge was impacting the $\mathrm{P}$ release and soluble $\mathrm{P}$ flux at 
the streambed sediment-water interface during low flow period.

\section{Materials and Methods}

\subsection{The Study Sites}

The experiments were undertaken in a micro-catchment (surface area $=2.4 \mathrm{~km}^{2}$ ) in the Bras d'Henri River catchment located within the agroclimatic region of ChaudiereAppalaches in southern Quebec, Canada (Fig. 1). This region is characterized by an intensive crop production and high livestock density (van Bochove et al. 2005). The micro-catchment has $53 \%$ of its area covered by annual crops (e.g., corn grain, soy bean), followed by forage $(30 \%)$, and forest $(13 \%)$. It also has a high animal production, with the animal density being 5.7 animal unit per hectare and the predominant animal mainly of hogs (59\%) and cattle (23\%). Soils were mainly sandy loamy in texture and equally podzolic versus gleysolic in nature. Stream water quality issues related to nitrogen $(\mathrm{N})$ and $\mathrm{P}$ losses in this area has been reported in previous studies (Corriveau et al. 2010b; Su et al. 2011).

In this micro-catchment, groundwater is discharged to streams all year long, and it is the dominant source of
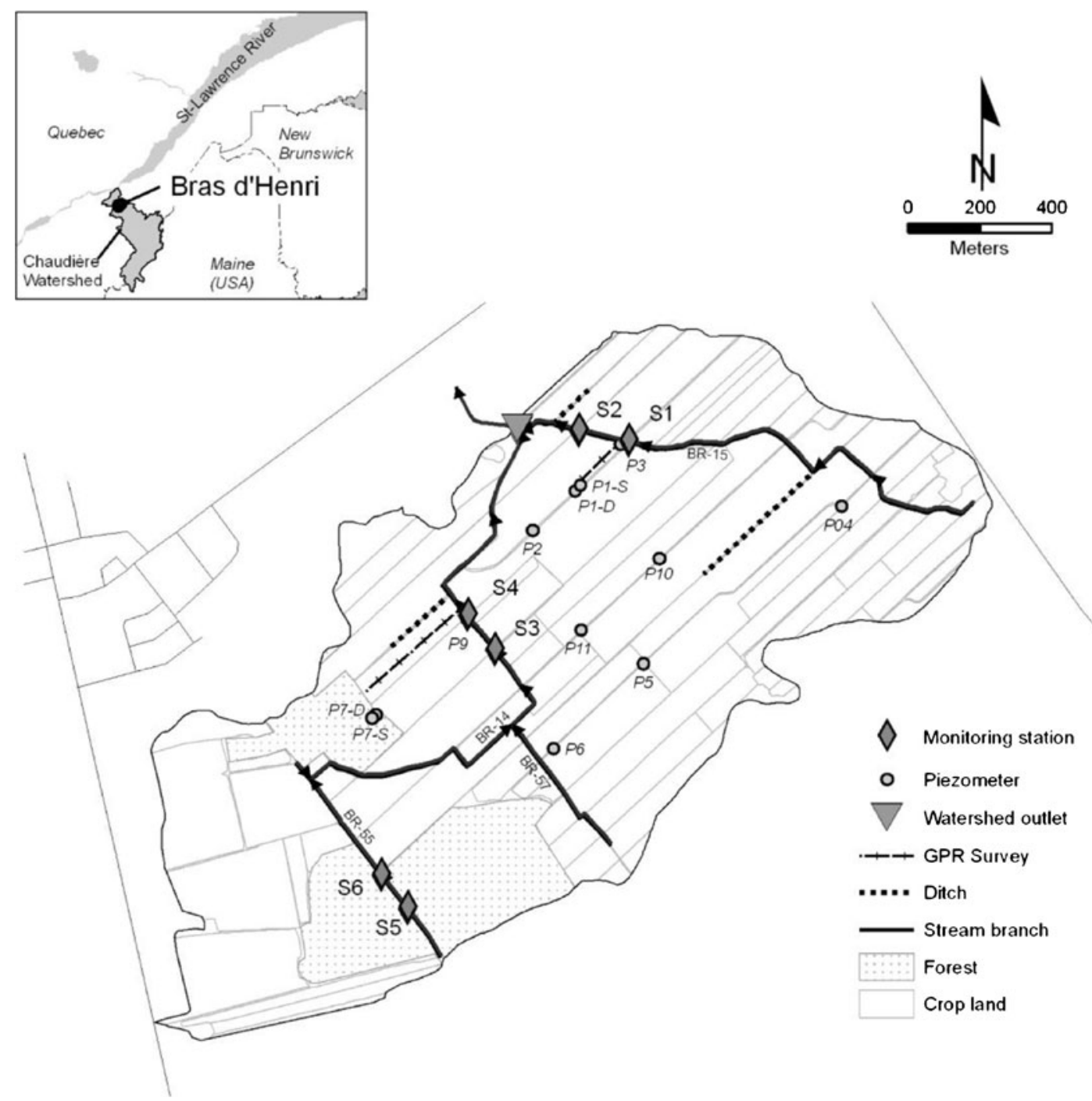

Fig. 1 Stream branches 14 and 15 and sampling sites S1, S2, S3, and S4 in the agricultural intervention micro-catchment located in the Bras d'Henri River catchment, Quebec, Canada 
water for streams during summer low water levels. The aquifer system in this micro-catchment has been well described by Corriveau et al. (2010b). Based on the groundwater chemistry results, geological soundings, and ground penetrating radar surveys, the aquifer system of the micro-catchment can be separated into a surficial and a regional aquifer. The surficial aquifer is unconfined and is composed of the littoral sediments of variable thickness and permeability, while the regional aquifer is a bedrock aquifer. Generally, the surficial and regional aquifers are separated by a layer of impermeable diamictons. This layer restricts the mixing of groundwater from both systems, as suggested by the groundwater chemistry from piezometers and domestic wells.

Br14 and Br15, dug in 1970s to improve land drainage, were the two major streams separately located in the south and north of this micro-catchment. They are characterized by steep slopes, unstable banks, and a water surface well below the bank level, even during flood events (Corriveau et al. 2010a). The channel widths of the two streams vary from 0.5 to $2 \mathrm{~m}$, and the water depths are about 15 to $35 \mathrm{~cm}$ during summer low water levels. Br 14 and 15 drain through comparable areas of 87 and 76 ha, respectively, both of which are dominated by crop land (50\% in Br14 and $73 \%$ in $\mathrm{Br} 15)$. The remaining drainage area was covered mainly by forest and pasture in $\operatorname{Br} 14$ while only pasture in Br15.

\subsection{Sampling}

In Br15, two sampling sites (S1 and S2) were located approximately $30 \mathrm{~m}$ apart from each other, upstream and downstream, respectively; while in Br14, sampling sites (S3 and S4) were located around $25 \mathrm{~m}$ apart (Fig. 1). Before the installation of water collecting devices, streambed sediment samples $(0 \sim 5 \mathrm{~cm})$ at each sampling site were collected with tubes made from polymethyl methacrylate (Plexiglas).

One empty PVC pipe (length $150 \mathrm{~cm}$ and diameter $20 \mathrm{~cm}$ ) was then hammered vertically into the streambed at each sampling site to a depth of around $45 \mathrm{~cm}$ beneath the streambed surface, avoiding the areas where sediment samples were taken (Fig. 2). This device was presumed to collect resurgence groundwater through the sediments (M.M. Savard and D. Paradis, personal communication), being surficial groundwater in Br15 and the mix of regional and surficial groundwater in Br14 in this study. The stream water initially trapped inside the pipes was pumped out with a syringe, and the pipe mouths were covered with plastic lids to avoid any precipitation deposition. The pipe water sampling started 4 days after the installation to allow sufficient water to seep through the sediments. Pipe water samples were collected by using a syringe, stored in $1 \mathrm{~L}$ highdensity polyethylene (HDPE) bottles, and placed in a $4{ }^{\circ} \mathrm{C}$ cooler. After each sampling, the pipe mouth was recovered by plastic lids.

A seepage meter to collect sediment pore water directly beneath the sediment-water interface was installed near the pipe in each sampling site, following the methods described by Corriveau et al. (2010a) (Fig. 2). The seepage meter consisted of a stainless steel container (diameter $0.25 \mathrm{~m}$ and height $0.18 \mathrm{~m}$ ), open at the bottom end and inserted vertically to the stream bed, enclosing an area of $0.05 \mathrm{~m}^{2}$ and small volume of overlying water. A flexible 2-L bag (Platypus, Seattle,

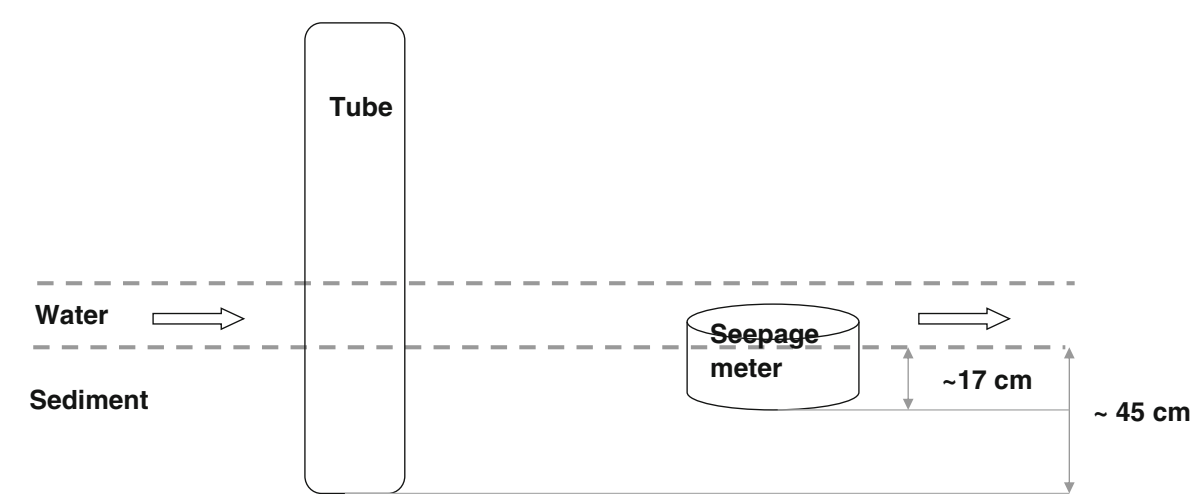

Fig. 2 Setup of the tube and seepage meter installed in the streambed sediments to sample resurgence water in each branch site S1, S2, $\mathrm{S} 3$, and S4 
Washington) was attached to a tube protruding from a rubber plug inserted in a hole in the top of the seepage meter. An air-evacuated flexible bag was installed on each device to collect water naturally seeping from the sediments. Bags were retrieved from the device, sealed tightly with acid-washed caps, replaced by new ones, and placed in a $4{ }^{\circ} \mathrm{C}$ cooler.

Stream water samples were collected at the same time as the pipe, and seepage water samples were collected. They were sampled about $1 \mathrm{~m}$ upstream of the pipe location to avoid any disturbance due to human movements in the stream, stored in 1 L HDPE bottles, and placed in a $4{ }^{\circ} \mathrm{C}$ cooler. All three types of water samples were transported back to the laboratory as soon as possible. The sampling was performed twice a week at an interval of 3 or 4 days from May 31st to June 28th, 2010.

Groundwater samples were collected from three piezometers (P1, P3, and P9) located nearby the Br14 and Br15 during low flow periods in 2007 and 2008, which were May 31st, June 29th, August 10th in 2007 and June 17th, July 25th in 2008 (Fig. 1). The piezometers were built using $5.0-\mathrm{cm}$ diameter PVC tubes, screened and sand packed at the water table to sample groundwater from the water table (Corriveau et al. 2010a). Samples from piezometers were collected in 2 L HDPE bottles, after a $10 \mathrm{~L}$ purge with an inertial pump. They were stored at $4{ }^{\circ} \mathrm{C}$ in a cooler and transported back to the laboratory as soon as possible.

\subsection{Sediment Analysis}

Sediments were air-dried, ground to pass $2 \mathrm{~mm}$ stainless steel sieves, and stored in plastic containers at ambient temperature. The sediments were analyzed for particle size, $\mathrm{pH}$, and loss on ignition (LOI). The sediment particle size was determined by a hydrometer method (Bouyoucos 1936). The $\mathrm{pH}$ was measured by a $\mathrm{pH}$ probe (Orion, Beverly, MA) at a sediment/water ratio of 1:10; and the LOI, widely used as a method to estimate organic matter, was measured by ignition at $550{ }^{\circ} \mathrm{C}$ for $16 \mathrm{~h}$ as described by House and Denison (1998).

\subsection{Water Analysis}

Immediately after returning to the laboratory, volumes of the pipe water and seepage water samples were recorded to estimate the water flux, and dissolved oxygen (DO) concentrations in seepage water samples were measured using a digital oximeter (MettlerToledo International Inc., $\mathrm{CH}$ ). $\mathrm{pH}$ and electric conductivity of the pipe and seepage water samples were then measured using a $\mathrm{pH} /$ conductivity meter (MettlerToledo International Inc., $\mathrm{CH})$.

All the water samples $(20 \mathrm{~mL})$ were filtered using $0.45 \mu \mathrm{m}$ Whatman membrane filters for the determination of DRP and dissolved cations ( $\mathrm{Fe}, \mathrm{Al}, \mathrm{Ca}, \mathrm{Mg}$, and $\mathrm{Mn}$ ). Part of the filtered seepage water samples were also used for the speciation of $\mathrm{Fe}^{2+} / \mathrm{Fe}^{3+}$. A $2 \mathrm{~mL}$ subsample of filtered seepage water samples were immediately transferred to tubes containing $0.2 \mathrm{~mL}$ ferrozine (monosodium salt hydrate of 3-(2-pyri-dyl)5, 6-diphenyl-1, 2, 4-triazine-p, p'disulfonic acid) reagent for further $\mathrm{Fe}^{2+} / \mathrm{Fe}^{3+}$ speciation according to the method proposed by Viollier et al. (2000). Dissolved reactive $P$ in filtered stream water, pipe water, and seepage water was determined by spectrophotometry (PerkinElmer Inc., MA) using the Murphy and Riley (1962) method, and the dissolved cations (Fe, Al, Ca, $\mathrm{Mg}$, and $\mathrm{Mn}$ ) were analyzed by ICP-OES.

Groundwater samples collected in 2007 and 2008 were filtered and analyzed using the methods described above for the 2010 water samples.

\subsection{Statistics}

A nonparametric Mann-Whitney $U$ test was utilized to test for significant differences of water characteristics of pipe water, seepage water, stream water (flux, $\mathrm{pH}$, conductivity, and DRP), and piezometer water $(\mathrm{pH}$, conductivity, DRP, and ions) between the two stream branches (probability level at 0.05). Results were presented in Tables 1 and 2.

Kruskal-Wallis (K-W) tests were used to explore whether there were overall significant differences in each variable of the seepage water characteristics among the four sampling sites $(k=4)$. If a significant result occurred for $k(k=4)$ groups $(p \leq 0.05)$, the groups were placed in order of ascending average rank. Then, new $\mathrm{K}-\mathrm{W}$ tests for the two possible comparisons between $(k-1)$ groups were performed, noting that this involves re-ranking the observations each time (Table 4). In order to control the overall error rate, the critical alpha values for the new $\mathrm{K}-$ $\mathrm{W}$ tests on subsets were calculated according to equation $\alpha_{(k-1)}=1-(1-\alpha)^{(\mathrm{k}-1) / \mathrm{k}}$, as recommended by Helsel and Hirsch (2002). The mean ranks were then interpreted as the estimates of the group median (see Table 4) (Helsel and Hirsch 2002). 
Table 1 Medians and means of water quality parameters measured in the pipe water, seepage water, and stream water in $\mathrm{Br} 14$ and $\mathrm{Br} 15$ during the observation period (May 31st-June 28th, 2010)

${ }^{\mathrm{a}} S E$ standard error

${ }^{\mathrm{b}}$ Letters represent the significant difference of the median values of water quality parameters between $\mathrm{Br} 14$ and $\mathrm{Br} 15$

\begin{tabular}{|c|c|c|c|c|c|}
\hline & Branch & Median & Mean & $S E^{\mathrm{a}}$ & \\
\hline \multicolumn{6}{|l|}{ Pipe water } \\
\hline \multirow[t]{2}{*}{ Flux $\left(\mathrm{mL} \mathrm{h}^{-1}\right)$} & $\operatorname{Br} 15$ & 5.70 & 5.10 & 0.81 & $b^{b}$ \\
\hline & Br14 & 0.31 & 0.33 & 0.06 & $\mathrm{a}$ \\
\hline \multirow[t]{2}{*}{$\mathrm{pH}$} & Br15 & 7.77 & 7.77 & 0.07 & $\mathrm{a}$ \\
\hline & Br14 & 8.18 & 8.14 & 0.04 & $\mathrm{~b}$ \\
\hline \multirow[t]{2}{*}{ Conductivity $\left(\mu \mathrm{s} \mathrm{cm}^{-1}\right)$} & $\operatorname{Br} 15$ & 611.50 & 592.71 & 20.69 & $\mathrm{~b}$ \\
\hline & Br14 & 465.00 & 483.17 & 24.41 & a \\
\hline \multirow[t]{2}{*}{$\mathrm{DRP}\left(\mathrm{mg} \mathrm{L}^{-1}\right)$} & $\operatorname{Br} 15$ & 0.057 & 0.062 & 0.008 & $\mathrm{a}$ \\
\hline & Br14 & 0.035 & 0.046 & 0.006 & $\mathrm{a}$ \\
\hline \multicolumn{6}{|l|}{ Seepage water } \\
\hline \multirow[t]{2}{*}{ Flux $\left(\mathrm{mL} \mathrm{h}^{-1}\right)$} & Br15 & 10.03 & 8.83 & 1.10 & $\mathrm{~b}$ \\
\hline & Br14 & 4.01 & 4.79 & 0.87 & $\mathrm{a}$ \\
\hline \multirow[t]{2}{*}{$\mathrm{pH}$} & Br15 & 7.44 & 7.49 & 0.10 & $\mathrm{~b}$ \\
\hline & Br14 & 7.23 & 7.22 & 0.07 & $\mathrm{a}$ \\
\hline \multirow[t]{2}{*}{ Conductivity $\left(\mu \mathrm{s} \mathrm{cm}^{-1}\right)$} & $\operatorname{Br} 15$ & 978.50 & 1093.00 & 132.02 & $\mathrm{~b}$ \\
\hline & $\operatorname{Br} 14$ & 638.00 & 617.62 & 31.80 & $\mathrm{a}$ \\
\hline \multirow[t]{2}{*}{$\mathrm{DRP}\left(\mathrm{mg} \mathrm{L}^{-1}\right)$} & $\operatorname{Br} 15$ & 0.038 & 0.046 & 0.010 & a \\
\hline & Br14 & 0.019 & 0.025 & 0.003 & $\mathrm{a}$ \\
\hline \multicolumn{6}{|l|}{ Stream water } \\
\hline \multirow[t]{2}{*}{$\mathrm{pH}$} & Br15 & 7.68 & 7.76 & 0.07 & $\mathrm{a}$ \\
\hline & Br14 & 7.58 & 7.58 & 0.05 & $\mathrm{a}$ \\
\hline \multirow[t]{2}{*}{ Conductivity $\left(\mu \mathrm{s} \mathrm{cm}^{-1}\right)$} & $\operatorname{Br} 15$ & 429 & 434.58 & 7.19 & a \\
\hline & $\operatorname{Br} 14$ & 443 & 420.67 & 24.19 & $\mathrm{a}$ \\
\hline \multirow[t]{2}{*}{$\mathrm{DRP}\left(\mathrm{mg} \mathrm{L}^{-1}\right)$} & $\operatorname{Br} 15$ & 0.023 & 0.026 & 0.003 & $\mathrm{~b}$ \\
\hline & Br14 & 0.012 & 0.022 & 0.005 & $\mathrm{a}$ \\
\hline
\end{tabular}

The normality of the datasets (concentrations of DRP and ions) in pipe water in each sampling site was tested by the Shapiro-Wilk test $(p>0.05)$. The Pearson correlation was then calculated on normally or approximately normally distributed data to test the significance of linear relationships between molar concentrations of DRP and ions $(p \leq 0.05)$.

\section{Results and Discussion}

\subsection{Characteristics of Pipe Water and Seepage Water}

Pipe water and seepage water were presumed to, respectively, represent resurgence groundwater and pore water directly beneath the sediment upwelling to the overlying water, as stated previously. Their flux rates reflected the magnitude for the beneath interstice water to seep through the sediments. Significantly greater fluxes were observed for both pipe and seepage waters in Br15 than in Br14 (Table 1), indicating a better permeability of streambed sediments in $\operatorname{Br} 15$ for the upwelling water. Visual inspection of the sampling sites in Br14 revealed areas covered by a discontinuous silt/clay layer which was likely to be the deposited gleysols from the nearby agricultural land. The presence of this clay layer possibly explained the lower water fluxes in $\mathrm{Br} 14$ streambed because it may prevent the flow exchange between sediment and stream water. Previous studies also reported similar result that fine sediment deposition in streambeds could reduce the sediment permeability and lead to the physical clogging of the heterogeneous interstices (Schälchli 1992; Rehg et al. 2005).

In both Br14 and Br15, the pipe water, seepage water, and stream water were characterized by neutral to slightly alkaline $\mathrm{pH}$, with the pipe water having the highest median value (8.05), followed by stream water (7.58) 
Table 2 Median and mean values of water quality parameters measured in three piezometers (see P1, 3, and 9 on Fig. 1) in the micro-catchment during summer low flow period in 2007 and
2008. The sampling dates were May 31st, June 29th, August 10th 2007 and June 17th, July 25th 2008

\begin{tabular}{|c|c|c|c|c|c|c|c|c|}
\hline & \multicolumn{4}{|c|}{ P9 (Br14) } & \multicolumn{4}{|c|}{$\mathrm{P} 1$ and $\mathrm{P} 3(\mathrm{Br} 15)$} \\
\hline & Median & Mean & $\mathrm{SE}^{\mathrm{a}}$ & & Median & Mean & SE & \\
\hline $\mathrm{pH}$ & 7.50 & 7.64 & 0.16 & $\mathrm{a}$ & 7.44 & 7.39 & 0.05 & $a^{b}$ \\
\hline Conductivity $\left(\mu \mathrm{s} \mathrm{cm}^{-1}\right)$ & 516.00 & 399.51 & 77.60 & $\mathrm{a}$ & 449.00 & 478.63 & 50.37 & $\mathrm{a}$ \\
\hline $\mathrm{DRP}\left(\mathrm{mg} \mathrm{L}^{-1}\right)$ & 0.001 & 0.015 & 0.007 & $\mathrm{a}$ & 0.000 & 0.003 & 0.002 & $\mathrm{a}$ \\
\hline $\mathrm{Ca}\left(\mathrm{mg} \mathrm{L}^{-1}\right)$ & 91.64 & 65.06 & 13.85 & $\mathrm{a}$ & 59.48 & 65.72 & 5.98 & $\mathrm{a}$ \\
\hline $\mathrm{Mg}\left(\mathrm{mg} \mathrm{L}^{-1}\right)$ & 6.98 & 6.59 & 0.81 & $\mathrm{a}$ & 6.43 & 7.75 & 1.40 & $\mathrm{a}$ \\
\hline $\mathrm{Al}\left(\mathrm{mg} \mathrm{L}^{-1}\right)$ & 2.88 & 14.42 & 10.95 & $\mathrm{a}$ & 2.78 & 9.14 & 4.51 & $\mathrm{a}$ \\
\hline $\mathrm{Fe}\left(\mathrm{mg} \mathrm{L}^{-1}\right)$ & 0.00 & 15.71 & 14.78 & $\mathrm{a}$ & 0.00 & 4.77 & 3.55 & $\mathrm{a}$ \\
\hline $\mathrm{Mn}\left(\mathrm{mg} \mathrm{L}^{-1}\right)$ & 24.87 & 18.76 & 4.88 & $\mathrm{~b}$ & 0.39 & 0.88 & 0.35 & $\mathrm{a}$ \\
\hline
\end{tabular}

${ }^{\text {a }} S E$ standard error

${ }^{\mathrm{b}}$ Letters represent the significant difference of the median values of water quality parameters between $\operatorname{Br} 14$ and $\mathrm{Br} 15$

and seepage water (7.32). Conductivity was significantly different among the three types of water, with the median values following in the order of seepage water (674)> pipe water $(576)>$ stream water $(431)(p<0.05)$. DRP concentrations in three types of water were in the order of pipe water $>$ seepage water $>$ stream water, with the median DRP concentration in the pipe water being significantly higher than that in seepage water and stream water $(p<0.05)$.

\subsection{Sources of DRP in Pipe Water}

Surficial groundwater in $\operatorname{Br} 15$ and a mix of regional and surficial groundwater in $\mathrm{Br} 14$ contributed to the pipe water. Table 2 summarizes the variables for groundwater collected in the piezometers close to our sampling sites

Table 3 Pearson correlations between molar concentrations of $\mathrm{DRP}$ and molar concentrations of $\mathrm{Al}, \mathrm{Ca}, \mathrm{Mn}, \mathrm{Fe}$, and $\mathrm{Mg}$ in the pipe water collected in sampling sites of $\operatorname{Br} 15$ (S1, S2) and sampling sites of Br14 (S3, S4) during May 27th to June 21st, $2010(n=7)$

\begin{tabular}{ccccccc}
\hline & & Al & Ca & Mn & Fe & Mg \\
\hline Br15 & S1 & -0.67 & $0.82^{*}$ & $-0.87^{*}$ & -0.60 & 0.74 \\
& S2 & 0.29 & 0.49 & -0.75 & $-0.87^{*}$ & 0.63 \\
Br14 & S3 & $-0.88^{*}$ & 0.25 & 0.22 & -0.41 & 0.07 \\
& S4 & 0.22 & 0.64 & 0.56 & 0.53 & 0.54 \\
\hline
\end{tabular}

*Represents significance $(p \leq 0.05)$ during the summer low flow period in 2007 and 2008. Mann-Whitney $U$ test showed that the groundwater recharging the $\mathrm{Br} 14$ and $\mathrm{Br} 15$ during the low flow period did not exhibit significant differences in $\mathrm{pH}$, conductivity, DRP concentrations, and metals except Mn (Table 2). DRP concentrations in groundwater were negligible $\left(<0.003 \mathrm{mg} \mathrm{P} \mathrm{L}^{-1}\right)$, with the median values being an order of magnitude lower than those found in the corresponding pipe waters $\left(>0.03 \mathrm{mg} \mathrm{P} \mathrm{L}^{-1}\right)$ (Tables 1 and 2). This implies that DRP in pipe water likely originated from other sources rather than groundwater DRP.

Figure 3 showed that DRP concentrations in pipe water collected in the same branch generally followed a similar time-varying pattern. Pipe water DRP concentrations were found to be significantly correlated between $\mathrm{S} 1$ and $\mathrm{S} 2(\mathrm{r}=0.87, p<0.05)$ and between $\mathrm{S} 3$ and S4 ( $\mathrm{r}=0.91, p<0.05)$, further suggesting the consistency of mechanisms for the occurrence of DRP in pipe water within the same branch. For S1 and S2 in Br15, the pipe water DRP concentration generally increased with time. This increasing phosphate presented in the pipe water might be due to the dissolution of sediment calcite (De Jonge and Villerius 1989). The calcite dissolution could be attributed partly to the increased dissolution of atmospheric $\mathrm{CO}_{2}$ in the pipe water. This process was especially obvious in S1, where the DRP molar concentration was significantly and positively correlated with the Ca molar concentrations in the pipe water, but was not significant in S2 (Table 3). The significant and negative correlations between the molar 
Table 4 Medians and means of water quality parameters measured in seepage water collected in the sampling sites of $\mathrm{Br} 15$ (S1, S2) and Br14 (S3, S4) during May 27th to June 21st, 2010

\begin{tabular}{|c|c|c|c|c|c|c|}
\hline & Branch & & Median & Mean & $\mathrm{SE}^{\mathrm{a}}$ & \\
\hline \multirow[t]{4}{*}{$\mathrm{DO}\left(\mathrm{mg} \mathrm{L}^{-1}\right)$} & $\operatorname{Br} 15$ & $\mathrm{~S} 1$ & 7.46 & 7.89 & 0.83 & $\mathrm{~b}^{\mathrm{b}}$ \\
\hline & & $\mathrm{S} 2$ & 1.34 & 1.35 & 0.32 & $\mathrm{a}$ \\
\hline & Br14 & S3 & 3.13 & 4.27 & 1.78 & $\mathrm{a}$ \\
\hline & & S4 & 2.46 & 2.41 & 0.74 & $\mathrm{a}$ \\
\hline \multirow[t]{4}{*}{$\mathrm{pH}$} & $\operatorname{Br} 15$ & $\mathrm{~S} 1$ & 7.79 & 7.80 & 0.08 & $\mathrm{~b}$ \\
\hline & & $\mathrm{S} 2$ & 7.14 & 7.18 & 0.05 & $\mathrm{a}$ \\
\hline & Br14 & S3 & 7.25 & 7.27 & 0.11 & $\mathrm{a}$ \\
\hline & & S4 & 7.15 & 7.16 & 0.07 & $\mathrm{a}$ \\
\hline \multirow{4}{*}{$\begin{array}{l}\text { Conductivity } \\
\qquad\left(\mu \mathrm{sm}^{-1}\right)\end{array}$} & $\operatorname{Br} 15$ & $\mathrm{~S} 1$ & 671 & 638 & 19 & $\mathrm{a}$ \\
\hline & & $\mathrm{S} 2$ & 1,595 & 1,548 & 78 & $\mathrm{~b}$ \\
\hline & Br14 & S3 & 567 & 551 & 44 & $\mathrm{a}$ \\
\hline & & S4 & 705 & 695 & 19 & $\mathrm{a}$ \\
\hline \multirow[t]{4}{*}{$\mathrm{DRP}\left(\mathrm{mg} \mathrm{L}^{-1}\right)$} & $\operatorname{Br} 15$ & $\mathrm{~S} 1$ & 0.062 & 0.060 & 0.008 & $\mathrm{~b}$ \\
\hline & & $\mathrm{S} 2$ & 0.008 & 0.014 & 0.005 & $\mathrm{a}$ \\
\hline & Br14 & S3 & 0.019 & 0.026 & 0.005 & $\mathrm{a}$ \\
\hline & & S4 & 0.018 & 0.024 & 0.003 & $\mathrm{a}$ \\
\hline \multirow[t]{4}{*}{$\mathrm{Fe}^{2+}\left(\mu \mathrm{mol} \mathrm{L} \mathrm{L}^{-1}\right)$} & $\operatorname{Br} 15$ & $\mathrm{~S} 1$ & 0.0 & 0.0 & 0.0 & $\mathrm{a}$ \\
\hline & & $\mathrm{S} 2$ & 124.9 & 173.5 & 35.2 & $\mathrm{c}$ \\
\hline & Br14 & S3 & 14.1 & 44.8 & 20.3 & $\mathrm{~b}$ \\
\hline & & S4 & 331.0 & 275.9 & 56.3 & $\mathrm{c}$ \\
\hline
\end{tabular}

${ }^{\text {a }} S E$ standard error

${ }^{\mathrm{b}}$ Letters represent the significant difference of the median values of water quality parameters among four sampling sites of seepage water

DRP concentrations and Mn or Fe suggested the occurrence of $\mathrm{P}$ re-adsorption on $\mathrm{Mn}$ or Fe in the pipe water. Therefore, the presence of DRP in the pipe water of $\mathrm{Br} 15$ was a result of combined $\mathrm{P}$ release from calcite dissolution and $\mathrm{P}$ re-adsorption on $\mathrm{Mn}$ or Fe. For S3 and S4 in Br14, there was not a clear temporal trend, although DRP concentrations in both sampling sites peaked during 10th to 14 th June, when continuous sunny weather and high temperatures may have increased decomposition of sediment organic matter. The molar concentrations of DRP in Br14 were not significantly correlated with the molar concentrations of $\mathrm{Ca}, \mathrm{Mn}$, or Fe as observed for Br15 (Table 3).

\subsection{Sources of DRP in Seepage Water}

The seepage water was assumed to represent the pore water in the sediments lying just below the sediment- water interface (Brock et al. 1982), which was constituted from the stream water and groundwater. The DO median values of $1.34,3.13$, and $2.46 \mathrm{mg} \mathrm{L}^{-1}$ suggested that in sampling sites $\mathrm{S} 2(\mathrm{Br} 15)$ and $\mathrm{S} 3$ and $\mathrm{S} 4$ (Br14), anaerobic conditions had been developing inside the seepage meter due to the lack of atmospheric $\mathrm{O}_{2}$ dissolution in the seepage meter water (Table 4). Belanger and Mikutel (1985) also reported the enclosure of streambed sediments by the seepage meter resulted in anaerobic conditions inside the samplers. The abundant presence of $\mathrm{Fe}^{2+}$ in the seepage water collected at S2, S3, and S4 further confirmed the occurrence of anaerobic conditions (Table 4). The reduction of $\mathrm{Fe} / \mathrm{Mn}$-bound $\mathrm{P}$ compounds is considered as a key process to release $\mathrm{P}$ from sediments to the water column (Einsele 1936; Mortimer 1941). However, no significant correlations could be observed between the concentrations of DRP and redox-sensitive metals like $\mathrm{Fe}$ or $\mathrm{Mn}$ in these three sites, and the molar ratio of DRP to $\mathrm{Fe}^{2+}$ was less than 0.032 with a median value of 0.0002 , which suggested a minor participation of the reducible $\mathrm{P}$ fraction in sediments to DRP concentrations in the seepage water. Considering the comparable DRP concentrations between seepage and stream waters of these three sites, we presumed that the DRP presented in the seepage water might largely originate from the influent flow of stream water to the sediments.

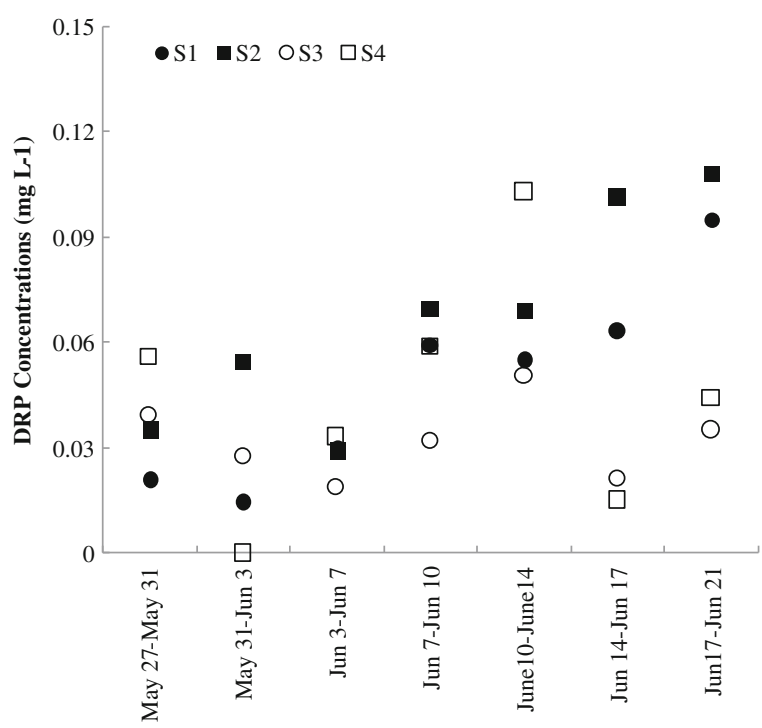

Fig. 3 DRP concentrations measured in pipe water collected in Br15 (S1, S2) and Br14 (S3, S4) during May 27th to June 21st in 2010 
At the sampling site S1, the seepage water was characterized by the highest $\mathrm{DO}$ content, $\mathrm{pH}$, and DRP concentration among the four sites and nearly undetectable concentrations of $\mathrm{Fe}^{2+}$ and total $\mathrm{Fe}$ (15.8 $\left.\mu \mathrm{g} \mathrm{L}^{-1}\right)$, suggesting an oxic environment inside the seepage meter and barely no reducing condition for Fe-bound P. This oxic environment could be partly attributed to the sediment texture in this site $(95 \%$ as sand and $5 \%$ as silt+clay) (Table 5), which allowed the penetration of dissolved $\mathrm{O}_{2}$ through the sediments. Comparing the DRP concentrations in seepage water, groundwater, and the stream water $(0.060,0.000$, and $0.023 \mathrm{mg} \mathrm{L}^{-1}$, respectively) (Tables 1 and 4), we concluded that DRP in seepage water of S1 mainly originated from the decomposition of organic matter or other unknown sources.

\subsection{Implications of Pipe and Seepage Meter Experiments}

Br14 was mainly supplied by the regional aquifer where anoxic conditions prevailed, while $\operatorname{Br} 15$ was mainly connected to the surficial aquifer which was characterized by high dissolved oxygen concentrations (Corriveau et al. 2010a). Thus, we expected that sediment $\mathrm{P}$ could be released to the pore water and then flow upward to streams with the groundwater or the mix of groundwater and stream water passing across the sediment-water interface during low flow period in Br14.

\subsubsection{Pipe Water Experiment}

The groundwater in both branches contained very low concentrations of DRP during low flow period, which did not constitute a direct source for the stream water DRP. However, the upwelling groundwater in $\mathrm{Br} 15$

Table 5 The particle size (\%), loss on ignition (LOI, \%), and pH in sediments collected in the sampling sites in $\operatorname{Br} 15$ (S1, S2) and Br14 (S3, S4) before experiments initiation

\begin{tabular}{lllllll}
\hline \multicolumn{1}{c}{ Clay (\%) } & Silt (\%) & Sand (\%) & LOI (\%) & $\mathrm{pH}$ \\
\hline Br15 & S1 & 2.5 & 2.5 & 95.0 & 0.59 & 7.63 \\
& S2 & 5.0 & 7.0 & 88.0 & 0.98 & 7.70 \\
\multirow{3}{*}{ Br14 } & S3 & 5.0 & 9.0 & 86.0 & 1.03 & 7.65 \\
& S4 & 5.0 & 9.0 & 86.0 & 1.07 & 7.71 \\
\hline
\end{tabular}

could cause calcite dissolution and consequently $\mathrm{P}$ release to the stream water when contacting with $\mathrm{CO}_{2}$ in air, which lowered water $\mathrm{pH}$. $\mathrm{In} \mathrm{Br} 14$, the presence of a visible clay layer in the streambed could prevent the flow exchange across the sediment-water interface. Although reduction of P-containing Fe/Mn compounds in the underlying sediments may have occurred due to the anoxic groundwater recharge beneath the layer of clay, released $\mathrm{P}$ was unlikely to be transported to the stream water, due partly to the poor hydraulic conductivity across the sediment-water interface and partly to the $\mathrm{P}$ capture by the surface sediment during transport. Penn et al. (2000) once pointed out that the trapping effect at the sediment-water interface may mask the dissolution effect occurring in deeper sediments. Therefore, the anoxic groundwater recharge to Br14 should not be a concern regarding $\mathrm{P}$ levels in the stream water in our sampling sites. However, the area covered by the sampling pipes was relatively small compared to the streambed section and may have misrepresented the conditions in $\operatorname{Br} 14$ because the clay layer was not present throughout the streambed. Thus, we are unable to draw a general conclusion regarding the influence of anoxic groundwater recharge on $\mathrm{P}$ behavior across the sediment-water interface at the scale of the entire branch.

\subsubsection{Seepage Meter Experiment}

The original purpose of using seepage meters in this study was to collect the sediment pore water under natural conditions and assess if sediment pore water characteristics could provide some insights into the redox conditions of the water-sediment interface and their influences on sediment $\mathrm{P}$ release. However, the anaerobic conditions created inside the samplers in S2, $\mathrm{S} 3$, and S4 and the site selection in S1 may not represent the real redox conditions in sediments and did not allow us to complete our original intent. But still, one point could be noticed from the experiment; under the created anoxic conditions, reduction of sediment $\mathrm{Fe}$ occurred but DRP present in seepage water was not closely associated with the reducible metals like Fe and $\mathrm{Mn}$. This may reflect that streambed sediments did not contain much P bound to reducible Fe/Mn. Sediment nature would more or less limit the amount of sediment $P$ released to the water column through mineral reduction reactions. 


\section{Conclusions}

Groundwater was not a major direct source of DRP in stream water of both branches because of negligible DRP concentrations. However, groundwater has the potential to contribute to stream water DRP indirectly by influencing the environment surrounding sediment $\mathrm{P}$ and consequently its release. In $\mathrm{Br} 15$, atmospheric $\mathrm{CO}_{2}$ dissolution in upwelling resurgence groundwater appears to have lowered the $\mathrm{pH}$ of the water causing the dissolution of sediment calcite and releasing $\mathrm{P}$ to the stream water. The pipe and seepage experiments did not provide direct information regarding the redox conditions at the sediment-water interface of Br14; but the seepage sampling indicated that in Br14, sediment $\mathrm{P}$ release due to the reduction of $\mathrm{P}$-containing $\mathrm{Fe} / \mathrm{Mn}$ compounds was not contributing to stream water $\mathrm{P}$ significantly. In addition, the presence of an impermeable clay layer over the streambed of $\mathrm{Br} 14$ prevented the transport of water and nutrients from the subsurface sediments to the stream water, further reducing the impact of groundwater on P flux across the sedimentwater interface. However, these conclusions were drawn based on limited sampling sites and more measurements are needed to assess the sediment-water interface role on DRP fluxes to the water column at the branch and catchment scales. Stream variability and heterogeneity in the streambed topography, sediment lithology, and hydrology rendered it too complex to precisely illustrate when, where, and to what extent $P$ fluxes in sediment-water interface were influenced by groundwater discharge.

Acknowledgments This study was made possible through the funding of both AAFC A-Base project \#263 and Bras d'HenriFourchette Watershed Evaluation of BMPs (WEBs) projects. The authors gratefully thank Nadia Goussard, Guillaume Bergeron, David Leduc, Marie-Eve Bernard, Etienne Dupont, and Martin Theriault for their excellent field and laboratory work, and Julie Corriveau for kind help in experimental plan.

\section{References}

Belanger, T. V., \& Mikutel, D. F. (1985). On the use of seepage meters to estimate groundwater nutrient loading to lakes1. Journal of the American Water Resources Association, 21(2), 265-272.

Bouyoucos, G. (1936). Directions for making mechanical analysis of soils by the hydrometer method. Soil Science, 42, 225-231.
Brock, T. D., Lee, D. R., Janes, D., \& Winek, D. (1982). Groundwater seepage as a nutrient source to a drainage lake; Lake Mendota, Wisconsin. Water Research, 16(7), 1255-1263.

Christophoridis, C., \& Fytianos, K. (2006). Conditions affecting the release of phosphorus from surface lake sediments. Journal of Environmental Quality, 35(4), 1181-1192.

Conley, D. J., Paerl, H. W., Howarth, R. W., Boesch, D. F., Seitzinger, S. P., Havens, K. E., et al. (2009). Controlling eutrophication: nitrogen and phosphorus. Science, 323(5917), 1014-1015.

Corriveau, J., van Bochove, E., \& Cluis, D. (2010a). Sources of nitrite in streams of an intensively cropped watershed. $\mathrm{Wa}$ ter Environment Research, 82(7), 622-632.

Corriveau, J., van Bochove, E., Savard, M. M., Cluis, D., \& Paradis, D. (2010b). Occurrence of high in-stream nitrite levels in a temperate region agricultural watershed. Water, Air, \& Soil Pollution, 206(1), 335-347.

De Jonge, V., \& Villerius, L. (1989). Possible role of carbonate dissolution in estuarine phosphate dynamics. Limnology and Oceanography, 34(2), 332-340.

Eckert, W., Nishri, A., \& Parparova, R. (1997). Factors regulating the flux of phosphate at the sediment-water interface of a subtropical calcareous lake: a simulation study with intact sediment cores. Water, Air, \& Soil Pollution, 99(1), 401-409.

Einsele, W. (1936). Über die Beziehungen des Eisenkreislaufs zum Phosphatkreislauf im eutrophen. Archives of Hydrobiology, 29(6), 664-686.

Grunth, N. L., Jensen, L. A., \& Elberling, B. (2008). Oxygen depletion and phosphorus release following flooding of a cultivated wetland area in Denmark. Geografisk Tidsskrift, 108(2), 17-25.

Gunnars, A., \& Blomqvist, S. (1997). Phosphate exchange across the sediment-water interface when shifting from anoxic to oxic conditions an experimental comparison of freshwater and brackish-marine systems. Biogeochemistry, 37(3), 203-226.

Haggard, B., Moore, P., \& DeLaune, P. (2005). Phosphorus flux from bottom sediments in Lake Eucha, Oklahoma. Journal of Environmental Quality, 34(2), 724-728.

Helsel, D. and Hirsch, R. (2002). Statistical methods in water resources: US Geological Survey Techniques of WaterResources Investigations, US Geological Survey.

House, W. A., \& Denison, F. H. (1998). Phosphorus dynamics in a lowland river. Water Research, 32(6), 1819-1830.

Lavoie, M., \& Auclair, J.-C. (2012). Phosphorus mobilization at the sediment-water interface in soft water shield lakes: the role of organic carbon and metal oxyhydroxides. Aquatic Geochemistry, 18(4), 327-341.

Lindsay, W.L., Vlek, P.L. and Chien, S.H. (1989). Minerals in soil environments, pp. 1089-1130, Soil Sci Am, Madison WI USA.

Moore, P. A., Reddy, K. R., \& Fisher, M. M. (1998). Phosphorus flux between sediment and overlying water in Lake Okeechobee, Florida: spatial and temporal variations. Journal of Environmental Quality, 27(6), 1428-1439.

Mortimer, C. H. (1941). The exchange of dissolved substances between mud and water in lakes. Journal of Ecology, 29(2), 280-329.

Murphy, J., \& Riley, J. (1962). A modified single solution method for the determination of phosphate in natural waters. Analytica Chimica Acta, 27, 31-36. 
Pagès, A., Teasdale, P. R., Robertson, D., Bennett, W. W., Schäfer, J., \& Welsh, D. T. (2011). Representative measurement of two-dimensional reactive phosphate distributions and co-distributed iron (II) and sulfide in sea grass sediment pore waters. Chemosphere, 85(8), 1256-1261.

Pant, H. K., \& Reddy, K. R. (2001). Phosphorus sorption characteristics of estuarine sediments under different redox conditions. Journal of Environmental Quality, 30(4), 1474-1480.

Penn, M. R., Auer, M. T., Doerr, S. M., Driscoll, C. T., Brooks, C. M., \& Effler, S. W. (2000). Seasonality in phosphorus release rates from the sediments of a hypereutrophic lake under a matrix of $\mathrm{pH}$ and redox conditions. Canadian Journal of Fisheries and Aquatic Sciences, 57(5), 10331041.

Petticrew, E. L., \& Arocena, J. M. (2001). Evaluation of ironphosphate as a source of internal lake phosphorus loadings. Science of the Total Environment, 266(1), 87-93.

Qian, Y., Liang, X., Chen, Y., Lou, L., Cui, X., Tang, J., et al. (2011). Significance of biological effects on phosphorus transformation processes at the water-sediment interface under different environmental conditions. Ecological Engineering, 37(6), 816-825.

Redshaw, C., Mason, C., Hayes, C., \& Roberts, R. (1990). Factors influencing phosphate exchange across the sediment-water interface of eutrophic reservoirs. Hydrobiologia, 192(2-3), 233-245.
Rehg, K. J., Packman, A. I., \& Ren, J. (2005). Effects of suspended sediment characteristics and bed sediment transport on streambed clogging. Hydrological Processes, 19(2), 413-427.

Schälchli, U. (1992). The clogging of coarse gravel river beds by fine sediment. Hydrobiologia, 235(1), 189-197.

Søndergaard, M., Jensen, J. P., \& Jeppesen, E. (2003). Role of sediment and internal loading of phosphorus in shallow lakes. Hydrobiologia, 506(1-3), 135-145.

$\mathrm{Su}$, J., van Bochove, E., Thériault, G., Novotna, B., Khaldoune, J., Denault, J., et al. (2011). Effects of snowmelt on phosphorus and sediment losses from agricultural watersheds in Eastern Canada. Agricultural Water Management, 98(5), 867-876.

van Bochove, E., Dechmi, F., Nolin, M., Chantigny, M., Lemieux, C. and Thériault, G. (2005). Evaluation of beneficial agricultural management practices on water quality at edge-of-field and micro-watershed scales in Southern Quebec, Canada, Johannesburg, South Africa.

Viollier, E., Inglett, P., Hunter, K., Roychoudhury, A., \& Van Cappellen, P. (2000). The ferrozine method revisited: Fe (II)/Fe (III) determination in natural waters. Applied Geochemistry, 15(6), 785-790.

Wang, H., Holden, J., Spera, K., Xu, X., Wang, Z., Luan, J., et al. (2012). Phosphorus fluxes at the sediment-water interface in subtropical wetlands subjected to experimental warming: a microcosm study. Chemosphere, 90, 1794-1804. 